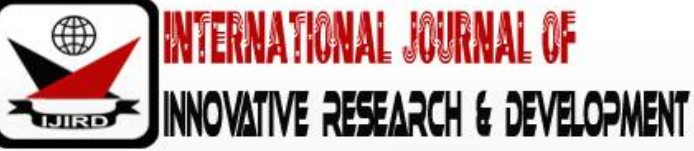

ISSN 2278 - 0211 (Online)

\section{Assessment of Dependency Media Theory on the Political Development of Eastern-Nigeria}

\author{
Afulike Don Christian \\ Assistant Lecturer, Department of Mass Communication, Abia State University, Uturu \\ Dr. Ekwueme Anthony \\ Senior Lecturer, Department of Mass Communication, University of Nigeria Nsukka, Nigeria
}

\begin{abstract}
:
This study examines the prediction that the media audience depend on the information to meet certain needs and achieve certain goals. Dependency relationship between the media and the audience is developed through media perspectives that tend to satisfy their (audience) economic political, policy and information needs. The research adopted a survey method approach; with a purposive sampling technique to select an equal representation in each states of south eastern Nigeria; with a population of 500; using mean for statistical analysis with 2:50 benchmark to analysed data; the study further discovered that the eastern Nigeria audiences depend on the media of communication through her roles of education, information, agenda setting, Propaganda and awareness to meet theirs socio-political needs or goals. The study therefore, recommended that the media should effectively and efficiently integrate the eastern Nigerians with supportive and coordinated political activities or programmes that could raise the developmental opportunities of the region.
\end{abstract}

Keywords: Media, dependency, development, eastern Nigeria, political

\section{Introduction}

The dependency media theory which was propounded by Sandra Ball-Roacheach and Melvin De Fleur in 1976 as cited in Ball-Rocheach etal (1984) explains the integral relationship among audiences, business of power politics. The theory further states that the media audiences depend on the media information to meet certain needs and achieve certain goals.

The history of the involvement of the mass media of communication in the politics of what later became Nigerian lies, perhaps in the fact that the media pioneered the basic functions of mass media of communication in Nigeria; that is educating information and entertaining; (Omu 1978) cited in (Okoro 2004).

The inseparability of political development from media of communication is very obvious, considering the fact that effective political participation is only proscribe in a communication environment. It is context of media communication as a conditio sine qua non in politics. That is to say that the media dependency by the audience describes the political outcome of any group, individual or region.

In Nigeria's political history, the press is credited with the propagation of the nationalist ideas in the country. Coleman (1967) cited in Okoro (2004) states that the press was the most potent instrument that was used in the dissemination of nationalism and racial consciousness. The fearless, hard-hitting journalistic style of the pre-independence period was, no doubt reflective as well as emblematic of Coleman's assertion.

Communication is a vital tool of political control and development. The mass media collect, process and disseminate news on development ventures and messages in order to bring about attitudinal change and make the audience to take appropriate decisions. (Kenechukwu, 2014). As an agent of mobilization, the media help to organize and mobilize citizens for societal objectives in the sphere of political development, work and religion. To this end, political development and communication provides the use of communication applied to the speedy transformation of a country and its people from poverty to a dynamic state of economic growth which makes possible greater social equality and the larger fulfillment of human potentials. Kenechukwu, (2015).

Emerging developments in political communication in Nigeria, starts with a cursory re-look at society-part of which describes the entity called "Nigeria." It is perhaps good to first remember why or how social entities tend to form into a defined nomenclature identifiable with a territory.

Indeed, scholarly observations of society over thousands of years, have formed a consensus that society tend to emerge and sustain or change as a result of either structural adjustment (otherwise called structural functionalism) or symbolic interactions of the human beings therein. The communication patterns, practice and norms through the mass media and other forms are hardly the same either in societies that are dominantly structural functionalists' or symbolic interactionism in nature. Therefore, these enduring perspectives about Eastern-Nigeria society, however not mutually 
exclusive of each other, have remained the dominant thought out of postulations about how we exist as a group of individuals with similar or varied political interest, Sambe (2015:113). In Nigeria, political interests leading to tussles, has led to regionalism, civil war, riots, rebellion, and terror-which Boko Haram, Biafra agitations, Niger Delta militancy are chiefly among.

It has been established that dependency of the media by South Eastern Nigeria audience is conceived as a relationship and interactions between media audiences and social systems. The relationship here is the fulfillment of one party's need and goal which is reliant on the resources of another party. Thus, the relationship between media and audiences in industrailized and information based societies; individuals tend to develop a dependency perspective on the media to satisfy the variety of their needs, which can range from information, economic, political candidacy, policy and voting decisions.

\subsection{The Problem}

It is an established fact that in every society (including the Eastern part of Nigeria) is a component of government and the governed; these can be seen as people, power, leadership and fellowship; authority and understanding and acceptance, which the media through her awareness and accountability roles stimulate in a given society. Thus, the audience tend to depend on the media to be part of the political process.

However, the factor remains what determine how government or authority is formed and changed are at the heart of every human existence. This is referred to as politics and political development' while on the other hand is the means and usage of all forms of media of communication channels towards the dissemination of political motivated messages towards political influence need some assessment. Morealso, the media influence of politcal activities and awareness on Eastern Nigerians is dependent on the audience acceptance and dependency of media content and information through political news, programmes and messages.

There is no doubt that several investigations, conceptual and empirical, were likely to have been made into the roles played by the Nigerian news media in generating conflicting opinions about political development of South East Citizens. Yet there was the need to examine public opinions, decisions, and influence on politics from the lens of how such opinions might have been' instigated by the news media's messages, using political propaganda, political advertising, news programmes, and campaigns discussion about the subject-matter in immediate social circles.

Put differently, this study investigates the comparative extents to which exposure to news media messages on South East residents and immediate social circles of the audience of political participants that can predict people's divergent opinions on politics within the geopolitical zone.

The rationale of inclusion of the assumption that news media messages and audience' immediate social circles was not likely to shape public opinions, independent of other social factors. In other words, it was assumed that if there could be any correlation between the predictors and the outcome variable, such correlation was not likely to be perfect. Noelle-Neumann posited that people's willingness to voice out an opinion on divisive issues depends on demographic factors (Noelle-Neumann cited in Hopkins, 2015). The stated research problem is distinctively re-articulated in the following research objectives and questions.

\subsection{Research Objectives}

- To ascertain the extent audiences of Eastern Nigeria depend on the media for political development

- To know if media dependency influences the political development of Southeastern- Nigeria.

- To examine the roles of media in Southeastern Political development.

- To determine the extent Southeasterners expose themselves to media contents

\subsection{Research Questions}

- Do Eastern Nigeria audiences depend on media for political development?

- What is the influence of media dependency on the political decision and development of Eastern-Nigeria.

- What are the roles of media in Southeast Nigeria political development?

- To what extent do the Southeasterners expose themselves to media contents?

\section{Literature}

\subsection{Media Dependency Concept}

In general, the extent of the media's influence on audience is related to the degree of media content and information dependency of individuals on the media. While the basic propositions put forward by studies on media dependency; states that there are social functions performed for an audience by the media and there are greater potential influence of the media on the audience.

More also, there are potentially three types of effects that will result from regular audience's dependency on the media: These effects includes; cognitive, effective and behavioural outcomes. Cognitive concept explains the changes in audience's attitudes, value and beliefs; also considering changes brought about the media in its role in political agenda setting. Affective concept explain the development of feelings of fear or anxiety about living as a result of over-exposure and dependent to media reports or contents; while the behavioural concept focuses on the discourse of "deactivation" which occurs when audience refrain from taking certain decision or actions that would have been taken had he/ she not been exposed to certain media messages of communication. (Ball-Roacheach and De Fleur, 1984) 


\subsection{Politics, Nature and Meaning}

Politics arises from accepting the fact that the simultaneous existence of different groups, hence different interests and different traditions within a territorial unit under a common rule (Crick, 1991:28) in Okoro (2004). There is no one definition of politics that holds the allegiance of all political scientists. Contending definitions reflect important epistemological and methodological disagreements within the discipline. Similarly alternative conceptions of politics construct the political worlds differently, in part because they derived from different understanding of reason, evidences, and explanation, and in part because they are informed by radically different understandings of human possibilities Hawke worth and Kogan (1992, p.24) cited in Okoro (2004, p.90).

Thus schalors such as (Lasswell 1950),(Certlin1964) and (Morgenthau 1967) cited in (Okoro 2004) conceive politics as a struggle for power. Within this frame of reference, individuals participate in politics in order to pursue their own selfish advantage. The central question for he political research then is "who gets what, when, how" (Lasswel). Such a research focus necessarily expands political inquiry beyond the bounds of governmental agencies, for although the official institutions of state constitute one venue for power struggle, they by no means exhaust the possibilities. Within this, politics is ubiquitous. However, the above contentions are flawed on the following grounds:

- It is not correct to present human beings as being driven by Libido dominandi:

- They tend to paint a picture whereby the moral scope of political action is partially excluded man is, in fact not generally and always driven by the quest for power, much of human actions derive from the moral realm.

In a bid to correct the above contentions, scholars who are generally classified as pluralist conceive politics as the process of interest accommodation. These include. (Lindblom 1965),(Crick 1962) etc. Their central argument is that individuals engage in politics to maximize a wide range of values. While some political actors may pursue their selfish advantage exclusively, other may seek altruistic ends such as equally, freedom, justice, an unpolluted environment, or preservation of 'partisan mutual adjustment' (Lindblom, 1965), a process of bargaining negotiating. Conciliation and compromise through which individuals seeking markedly different objectives arrive at decisions with which all are willing to live. On this view, politics is a moderating actively, a mechanism for deciding policy.

Objectives from a competing array of alternatives (Crick, 1962) cited in (Okoro 2004)

However, the above failed to provide a comprehensive conception of politics. It tends to relegate war, revolution, terrorism beyond the spheres of politics. Besides, the notion of equal rights of participation and influence negates the formidable power of state and economy in determining political outcome, Perhaps a better way to conceptualize politics and its essence is to locate the explanation(s) within the ambit of those actions and inactions which directly or indirectly relate to mobilization and administration of human and maternal resource, for specific ends in a given political entity. In a rather restricted sense, Weber conceives politics as "all those human activities that arc directed towards, and indeed reflected to the process of acquiring, using and maintaining governmental power". Moreover, in what appears to be a modification of Weber's definition, Nnoli (2003: 12) defines politics as "all actions or activities that are directly or indirectly associated with emergence, consolidation and use of state power"

\subsection{Political Imperatives of the Mass Media}

The mass media in Nigeria have been deeply involved with politics, and have also been vital to political developments of the country. Goldin (1983) in (Sambe 2015, p. 116)asserts that the Nigeria press (journalism) was born of anti-colonial protest, baptized in the flood of nationalists' propaganda and matured in party politics." The media have also being from time to time, accused of sabotage of the political process or at least making it complicated to be followed and understood by the populace. According to Umechukwu (2001, p.85), in Double Gist (2013, p.I), "the Nigerian press have often been accused of aggravating the ugly situation through sinister prevarication in their reportage of events(politics, riots, religion, conflicts) etc."

The press in the First Republic was mainly characterized by the political struggles of the three major regions Northern, Western and Eastern regions. All the political parties had ethnic colorations and ties with respective regions. The regions, along with the press controlled the various agenda; and there existed a penchant for character assassinations at the time. The look at the nature of the electronic media at the time, reveals that they all existed- to represent the aspirations of their respective regions and not necessarily information dissemination via observation of ethical professional journalism. (Omu 1979,p. 246).

While between 2007, 2015 and post 2015; the political situations and development have been with regionalism and ethnicism leading to hate speeches with the PDP, ANPP, ACN, APGA, CPC and later APC at the plash point of accusations and counter accusations of marginalization and political intimidations; as reported by the mass media.

\subsection{Concept of Audience and Media}

According to McQuail (2009), "the mass media institution is part of the structure of society," and McQueens (1999) in Daramola (2003) stated that the audiences of the mass media have been influenced to a large extent by the mass media. In. the Mass society theory of the media. McQuail points out that the public becomes atomized in the sense that the conduct of people and indeed everything seems the same because of exposure to the media, people come to depend on the media for their Ideality and that the media are used for manipulations and control.

The result of this is that the society becomes influenced by modern mass media techniques, such as propaganda, advertising, framing, agenda setting. Daramola (2003) and McQuails (2009) are of the view that the mass media reach heterogeneous audiences that are diverse in various ways such as age, gender, education, religion, political knowledge among others. 
The influence of the mass media on the audience is not uniformed, putting in focus the complex nature of the recipients of mass media messages. Hwang, et al (2007) in McQuail (2009) notethateach person has unique and preexisting residue of knowledge, beliefs and expectations. Media effects on individuals depend on the extent to which the information contained in the message agrees with the individual's predisposition. They explain that as a message is processed by the audience, activation occurs. This is used 'to refer to a process in which relevant schemas and their constructs may become more accessible for subsequent judgments.

The audience is viewed as a discriminatory mass, which already have existing schema to interpret stories from the mass media. A schema according to Scheufele and Tewksbury (2007) refers to the knowledge that is developed gradually and becomes complex overtime and is related to personal experiences and associated feelings.

\subsection{Setting Agenda and propaganda}

Politics and communication seem to agree that the "game" of politics have become "mediatized," and politics to have become intertwined with media and mass communication. Sambe (2015).

Nwokea for and Adekunle (2013, pp.5-11), says that through the media, political campaigns, introduction of party candidates and their-manifesto are made popular towards a candidates support. While considering further the agenda setting theory, some scholars like Garret (2010) cited in Nwokeafor and Adekunle (2013, pp.5-11) thinks that the so called media role in political communication is to mislead the populace into a particular way of thinking and indeed perception. This in turn may be considered as propaganda

The comments by Graber (1990), as cited in Nwokeafor and Adekunle (2013:12) correlates that the mass media expected to structure voters' perceptions of political exigencies and reality. The entire thinking of the mass audience is expected to be a result of the reportage and coverage of issues by the media. This is where the considerable influence and agenda setting perspective grows from. Through such processes of political communication, the makeup of the most vital angles of discuss in a polity become an agenda for any particular election.

Nwokeafor and Adekunle (2013:12) insists that "in view of their power, the media controls the political messages, influences the political playing field in which an election campaign is conducted and in most instances defines the agenda that would assist a particular party win election." Indeed, the understanding is that "The media by playing the agendasetting role has purposely and deliberately created an agenda to control the sphere of information available to the public" (Nwokeafor and Adekunle 2013:20).

As a result of the foregoing, the assumption is that agenda setting role of the media is reflective in the way the media highlights other issues above some and directs the perception of the masses to such issues as been most important, thereby setting the agenda. However, Garret (2010) in Nwokea for and Adekunle (2013, pp.5-11), contends that agenda setting assumptions lead into the masses, largely been deceived via methods like the use of billboards and sticker slogans such as "change we can believe in;" "if I can make it to the presidency of Nigeria, you can also, make it." "During my early school days, I didn't have shoes." "I am for nobody but for everybody" "You first if I win you win". Nwokea for and Adekunle (2013, pp.5-11) citing McCombs and Shaw, (1972) understands that such sound bites or slogans emit emotions on the people and make them to identify and empathize with the candidate. The media capitalizes on this slogan, and sometimes use it for a commercial jingle and ran it as often as possible as it finally becomes not only what people think but also what they should think about.

It resonates that the media through the capacity to set agenda, media in political communication most times results to propaganda. Understandably, the term has been used connotatively in the negative sense. According to McQuail (2005:529), there is an impression that it is the "enemy" that makes propaganda, while 'our side' provides information, evidence and argument. McQuail (2005) sustains that propaganda has been applied to any almost any area where communication is planned to achieve some goal of influence it differs in some respect from simple persuasion attempts. It can be coercive and aggressive in manner; it is not objective and it has little regard for truth, even if it is not necessarily false, since sometimes the truth can be good propaganda. It comes in a range of types from deceptive, frightening and unscrupulous to soft and with a selective use of truth. An example is the social media campaign against the military vaccination exercise in some South East states at the eve of Anambra gubernatorial elections in 2017.

But why the often use of the word "propaganda" in political communication? Jowett and O'Donnell $(1999$, p. 6$)$ in McQuail(2005, p.529) defines propaganda as "the deliberate, systematic attempts to shape perception, manipulate cognitions, and direct behaviour to achieve a response that furthers the desired intent of the propagandist."

Going further on the postulations of the agenda setting, media role and how it has often been used in political communication. McQuail, (2005, p.523-524) say the following:

There has always been an intimate connection between mass communication and the conducts of politics, in whatever kind of regime; in totalitarian or authoritarian societies, ruling elites use their control of the media to ensure conformity and compliance and stifle dissent by one means or another. In democracies, the media have a complex relationship with sources of power and political system. On the other hand, they usually undertake their services to the audiences, to whom they provide information and views according to judgments of interest and need. In order to perform this service, they need to be independent of the state and powerful interest. On the other hand, they also provide channels by which the state and powerful interests address the people, as well as platforms for the views of political parties and other interests groups. They also promote the circulation of news and opinion within politically interest groups.

In Eastern Nigeria, some political actors believed that APGA as a party shares Eastern or Igbo coloration. Thus they go with a slogan "Nkabunke' anyi" (this is our own).While they perceived other national parties like APC as Fulani- 
Northern movement. This views, escalated through individual opinion using mainstream and social media during and after the September 2017 military invasion of IPOB leaders residence in Umuahia, Abia State.

\section{Theoretical Framew ork}

The theory underlying this study is Dependency Media theory. The concept of dependency deals with explanation of relationship between the content of the mass media, the nature of society and the communications behavior of audiences. People are dependent on media for their political process, development and other needs People in all societies (with Eastern-Nigerians inclusive) need information in order to make decisions about such matters as food, shelter, employment political and electoral issues and aspects of life. In traditional societies, people tend to pursue similar ways of life establishing networks of the kinships, long term neighbors, and other social ties from which they obtain the information that they need. Thus, people in both rural and urban societies across the Eastern Nigeria are dependent on the mass media for information needed to make any kind of decisions (including taking a political position).

\section{Method}

The research design adopted for this study was survey method approach; with a purposive sampling technique to select an equal representation in each states of South Eastern Nigeria.

This study had a population 500 Eastern Nigeria residents across the five South Eastern States of Abia, Anambra, Ebonyi, Enugu and Imo. Thus, one hundred respondents were selected from the respective states as highlighted.

\section{Findings}

5.1. Do Eastern Nigeria Audiences Depend on Media for Political Development?

\begin{tabular}{|c|c|c|c|c|c|c|}
\hline S/ N & Media Dependency & SA & A & D & SD & Mean \\
\hline 1 & Depend on media political programme daily & 226 & 178 & 73 & 23 & 3.21 \\
\hline 2 & Listen and read political news stories & 195 & 167 & 110 & 28 & 3.04 \\
\hline 3 & Always following TV political presentations & 210 & 184 & 74 & 32 & 3.13 \\
\hline 4 & $\begin{array}{c}\text { Following radio arguments and people's } \\
\text { view on politics weekly }\end{array}$ & 214 & 148 & 99 & 39 & 3.07 \\
\hline 5 & $\begin{array}{c}\text { Read newspapers for political updates and } \\
\text { analysis Bi-weekly }\end{array}$ & 157 & 194 & 89 & 60 & 2.89 \\
\hline & Bench Mark 2.50 & & & & GM & 3.07 \\
\hline
\end{tabular}

Table 1: Extent to Which Audiences Depend on Media for Political Information

Table reveals the respondent responses on their dependency for media in eastern Nigeria. Item 1 revealed with mean 3.27 depend on daily media programme on politics, while item 2 and 3 mean 3.04 and 3.13 listen, read (newspapers) and always following TV political presentations, item 4 and 5 with mean 3.07 and 2.89 revealed that some audiences follow radio arguments and peoples view on political development and read newspapers for political analysis.

\subsection{What Is the Influence of Media Dependency on The Political Decision and Development of Eastern Nigeria?}

\begin{tabular}{|r|c|c|c|c|c|c|}
\hline S/ N & Influence of Media Dependency & SA & A & D & SD & Mean \\
\hline 1. & $\begin{array}{c}\text { The media enlightens the people on political } \\
\text { happenings in the states of South East. }\end{array}$ & 224 & 177 & 76 & 23 & 3.20 \\
\hline 2. & $\begin{array}{c}\text { The media influences the political behavior of } \\
\text { Eastern Nigeria electorates. }\end{array}$ & 194 & 168 & 110 & 28 & 3.05 \\
\hline 3. & $\begin{array}{c}\text { The media compels the leaders to work for the } \\
\text { people. }\end{array}$ & 209 & 184 & 74 & 33 & 3.13 \\
\hline 4. & $\begin{array}{c}\text { The media helps in creating either negative or } \\
\text { positive awareness the Eastern Nigerians. }\end{array}$ & 214 & 149 & 98 & 39 & 3.07 \\
\hline 5. & $\begin{array}{c}\text { The media influences the way the masses view } \\
\text { politics and it outcome. }\end{array}$ & 158 & 193 & 89 & 60 & 2.89 \\
\hline & Bench Mark-2.50 & & & & G.M & 3.06 \\
\hline
\end{tabular}

Table 2: Influence of Media Dependency

Table reveals the respondents' responses on the influence of media dependency in Eastern Nigeria. Item 1 revealed with a mean score of 3.20 that the media enlightens the people on the political happenings in the state, while items 2 and 3 revealed with mean scores of 3.05 and 3.13 that the media influences the political behaviour of the electorates and also that the media compels the leaders to work for the benefit of the people. Items 4 and 5 revealed with mean scores of 3.07 and 2.89 that the media helps in creating either negative or positive awareness amongst the Eastern Nigerians and also influences the way the masses view and perceive politics and the outcome. 
5.3. What are the Roles of Media in Political Development Eastern Nigeria?

\begin{tabular}{|l|l|c|c|l|l|l|}
\hline S/ N & \multicolumn{1}{|c|}{ Questionnaire on Roles of Media } & Sa & A & \multicolumn{1}{c|}{ D } & \multicolumn{1}{c|}{ Sd } & \multicolumn{1}{c|}{ Mean } \\
\hline 1. & Educational role & 204 & 108 & 112 & 76 & 2.86 \\
\hline 2. & Behavioral orientation & 211 & 142 & 101 & 46 & 3.03 \\
\hline 3. & Political Activities & 223 & 194 & 62 & 21 & 3.23 \\
\hline 4. & Agenda setting, propaganda and informative role & 184 & 132 & 123 & 61 & 2.87 \\
\hline 5. & Electoral Values & 197 & 141 & 112 & 50 & 2.97 \\
\hline 6. & Bench mark-2.50 & & & & G.M & 2.99 \\
\hline
\end{tabular}

Table 3: Roles of Media in Political Development

Table 2 revealed the respondents' responses on the roles of media in the political developments in Eastern Nigeria. All items revealed mean scores above the criterion bench mark of 2.5 which is an indication that the media played several roles in the political development in Eastern Nigeria. Item 1 revealed with a mean score of 2.86 that the media play educational roles in the enlightenment of the masses politically, while items 2 and 3 revealed mean scores of 3.03 and 3.23 that the media shapes the behavioral orientation and also enlightens the masses on political activities. While item 4 and 5 revealed mean scores of 2.87 and 2.97 that the media inform the masses on political occurrences via agenda setting, propaganda and electoral values respectively.

\subsection{To What Extent do the Southeasterners Expose Themselves to Media Contents?}

\begin{tabular}{|c|c|c|c|c|c|c|}
\hline $\mathbf{S} / \mathbf{N}$ & Extent of Media Influence & SA & $\mathbf{A}$ & D & SD & Mean \\
\hline 1. & $\begin{array}{l}\text { The media enlightenment/ content exposureon } \\
\text { audience choice of political party }\end{array}$ & 184 & 188 & 74 & 54 & 3.00 \\
\hline 2. & $\begin{array}{l}\text { The media exposure/ influence on the choice of } \\
\text { political candidate }\end{array}$ & 156 & 178 & 103 & 63 & 2.85 \\
\hline 3. & $\begin{array}{l}\text { The media awareness/ orientation on political values } \\
\text { and outcome. }\end{array}$ & 232 & 102 & 85 & 81 & 2.97 \\
\hline 4. & The media exposure/ attitudunal influence to vote & 198 & 146 & 94 & 62 & 2.96 \\
\hline 5. & $\begin{array}{c}\text { The media enlightens the masses to the right values } \\
\text { of politics }\end{array}$ & 204 & 179 & 74 & 43 & 3.08 \\
\hline & & & & & & 2.97 \\
\hline
\end{tabular}

Table 4: Extent to Which the Audience Expose Themselves to Media Contents

Table 3 revealed the respondents' responses on the extent to which media message exposes and influence political developments in Eastern Nigeria. All mean score returned scores higher than the criterion bench mark of 2.5. This implied that the media message influences the populace to a very high extent. item 1 revealed that the media enlightens the people on choice of political party of 3.00, while item 2 and 3 revealed with mean scores of 2.85 and 2.97 that the media exposure influences the choice of candidate and also that the media create a strong value for voter orientation and political outcome. Finally, items 4 and 5 revealed that the media exposure determines the audience attitude to vote and the media also enlightens the masses to the rights and values of politics with mean scores of 2.96 and 3.08. The media influences the populace to a very high extent.

\section{Discussion}

\subsection{RQ1: Do Eastern Nigeria Audiences Depend on Media for Political Development?}

The study strongly revealed that the audiences of South East Nigeria depend on media reports about politics. Item 1 and 2 with mean 3.21 and 3.04 depend on media to inform them on daily political programme and political news stories. Item 3 and 4 with mean 3.13, 3.07 respectively follow political presentation on the television and radio arguments and people's view. While item 5 with mean 2.89 identified the group that read in bi-weekly newspaper's political analysis. Thus, supporting what Ball-Rocheach et al (1984) said that media audience depend on media information to make decisions, meet certain needs and achieve certain goals.

\subsection{RQ2: What Is the Influence of Media Dependency on the Political Decision and Development of Eastern Nigerians?}

The study revealed that the media inform and enlighten eastern Nigeria audiences as seen in item 1 with 3.20 mean; thus, item 2 and 3 with mean score 3.05 and 3.13 respectively revealed that they depend on the media to create awareness of political department, compel political leaders to perform their statutory functions; which could go a long way to make or mar the region development. This explains the predictions of Sandra Ball-Roacheach and de fleur 1976; which states that there is an integral relationship among audience and business power of politics; and that the audience depend on the media to meet their socio-political and economic needs. 


\subsection{RQ3: What Is The Role of the Media in the Political Development of Eastern Nigeria?}

South east audiences of mean 2:86, 3:03 share the media roles of educating the society, bringing behavioural orientation and political activities; while audiences of the mean 2:87 and 2:97 believed that the media set political agenda for eastern Nigerians, create propaganda, bring information and create electoral values. Therefore, supporting Omu (1978) cited in Okoro (2004) and Sambe (2015) which states that the media pioneered the basic functions of educating, informing, setting agenda, and political propaganda respectively.

\subsection{RQ4: To What Extent Do the Southeasterners Expose Themselves to Media Content?}

Media audiences of the mean 3:00, 2:85 and 2:85 and 2:97 believed that the media enlightment, political messages and exposure influences the audience choice of political party, choice of political candidates, with a strong value to voter orientation and political out comer while audiences of the mean 2:96 and 3:08 believed that the media determines people's attitude to vote and creating the right values of politics. Thus, supporting crick (1991) in Okoro (2004) that the exposure and influence of media extent can create existence of different group, hence difference interest under come rule.

\section{Conclusion}

The perspectives noted herein are drawn fundamentally from the bases of the society, the essence of the game of politics nature and role the media, political participation, as well as the relationship among the media, the audience and the business of politics in Nigeria. Quite a lot have been said and conceptualized about the contemporary and emerging political development in eastern Nigeria. Thus, the conventional and mainstream media have been heavily used for political purposes. However, the media have also had generous in-roads in the political communication scheme of the eastern region and the country at large.

\section{Recommendations}

- The media should always carry out the function of informing and educating south east media audiences on the national and local political breakthrough this well further help to motivate more political participation

- Media through effective and efficient integration with the audiences/ people of eastern Nigeria, should run a supportive and coordinated political programmes that could create socio-political and economic opportunities to better the life in the region.

- Because people depend on the media to make choices and to meet certain needs; the media should create political programmes that can shape political culture and other social conditions of Eastern Nigeria's citizens.

- That the media should improve in her programmes of contemporary political discourse and analysis that could convince the Eastern Nigerians on the need to always depend on the media for political, economic and information needs.

\section{References}

i. Anaeto, S, Onabajo, O and Ositeso, J. (2008) Models and Theories of Communication. Maryland: African Renaissance Books.

ii. Ball-Rocheach, S.J.M, Rocheach and Grube, JW (1984) The Great America. Value Test. Psychology Today, November, p.34 - 41

iii. Daramola, I. (2003) Introduction to Mass Communication. $2^{\text {nd }}$ ed. Lagos Rothan Press Ltd.

iv. Double Gest (2013). The Press in Nigeria Politics: Analysis of Issues and Patterns of news coverage: Retrieved from http/ www.doublegist.com

v. Kenechukwu S, (2015) New World Information and Communication Order. Government International Journal for Strategic Research in Education Technology and Humanities, 2(2)

vi. Kenechukwu, S. (2014) Mass Communication: An Introduction to Sociology of Mass Media. Nnewi, Cath Corm Press

vii. Kenechukwu, S.A., Eze, C and Abuah, F. (2014) Promotions of Media Enterpreneurship for National Development, Uyo: Art Climax Publishers.

viii. Kenechukwu, S.A., Eze, C and Abuah, F. (2015) Communication and Economic Development, Uyo. ACCE Books.

ix. McQual, D (2009) McQual's Mass Communication Theory (6 ${ }^{\text {th }}$ ed) London. SAGE

x. McQuall, D (2005) McQuall's Mass Communication Theory. (5 th $^{\text {Ed}}$ ) London. Safe Publications

xi. Nnoli, O (1978) Ethnic Politics in Nigeria Enugu: Fourth Dimension Publishers

xii. Nwokeafor, C and Okunoye, A. (2013) Media Power in Elections. Role of Agenda Setting theory in Political Communication in Nigeria Evolving Democracy. A paper presented at the International Conference on ICT for Africa. Harare, Zimbabwe. February 20 - 203

xiii. Okoro, N. \&Okolie, A. M (2004) Law, Politics and Mass Media in Nigeria. Nsukka, Prize Publishers

xiv. Omu, F (1978) Press and Politics in Nigeria 1880 - 1973, London. Longman

xv. Omu, F (1979) Press, Communication and Nigeria London. Longman

xvi. Oyebode, M. (2004), Use and misuse of New Media for Political Communication in Nigeria's $4^{\text {th }}$ Republic. Vol. 4. No. 2

xvii. Sambe,J.A (2015) Emerging Developments in Political Communications in Nigeria, Enugu RhyceKerex Publishers

xviii. Scheufele D.A (1999), Framing of News Coverage and Reporting. Journal of Communication 42(3)

xix. Scheufele, D.A and Tewsbury (2007) Framing, agenda-setting and priming: The evolution of media effects model. Journal of communication, $57(2)$ 